\title{
Infrastructure and Leading Commodity Identification on Poverty Alleviation in Buru Regency, Indonesia*
}

\author{
Tri WAHYUNINGSIH ${ }^{1}$, Arsad MATDOAN ${ }^{2}$, Zubair SAING $^{3}$
}

Received: September 10, 2020 Revised: November 08, 2020 Accepted: November 16, 2020

\begin{abstract}
The poverty level in Buru Regency is still high, despite the relatively stable economic growth. For this reason, the purpose of this study was to (1) Identify the leading commodity in each district in Buru Regency; (2) Analyze the effect of road infrastructure and leading commodities on poverty. The findings show that the most sparsely populated district is Fena Leisela, with mangoes as the leading commodity. Pineapple, langsat, apple rose, cabbages, cashews, coffee, cashew, melon, and watermelon are the leading products in Air Buaya, Batabual, Waplau, Lolong Guba, Lilialy, Waelata, Namlea, Kaiely Bay, and Waeapo, respectively. Additionally, the results also indicate that road infrastructure and leading commodities have a significant effect on poverty alleviation in Buru Regency. It means that improving infrastructure and increasing leading commodities production reduce poverty in the region. Good road infrastructure can promote connectivity between regions so that it can accelerate and expand economic development. The provision of infrastructure that encourages connectivity will reduce transportation costs and logistics costs to increase product competitiveness and accelerate the economic movement. When the road infrastructure in Buru Regency improves and new roads are built, it can improve transportation access, it will reduce the living cost for the poor and increase income, and open up opportunities for the poor to benefit from economic growth.
\end{abstract}

Keywords: Poverty, Infrastructure, Leading Commodities, Inclusive Growth

JEL Classification Code: I32, I38, O13, O18

\section{Introduction}

Maluku is an archipelago province with excellent marine potential, though it has always been famous for its

\footnotetext{
*Acknowledgments:

The authors express their gratitude to those who helped and supported the writing of the report, as well as to the entire community of Buru Regency and sub-district leaders. Additionally, the authors also appreciate and thank the reviewers who corrected and improved the report.

${ }^{1}$ First Author. Associate Professor, Department of Management, Faculty of Economics, Universitas Iqra Buru, Indonesia.

Email:wahyu040578@gmail.com

${ }^{2}$ Lecturer, Department of Management, Faculty of Economics, Universitas Pattimura, Indonesia.

Email: matdoanarsyad20@gmail.com

${ }^{3}$ Corresponding Author. Associate Professor, Department of Civil Engineering, Faculty of Engineering, Universitas Muhammadiyah Maluku Utara, Indonesia [Postal Address: Kampus UMMU Jalan KH. Ahmad Dahlan 100, Ternate, Maluku Utara, 97719, Indonesia] Email: zubairsaing.ummu@gmail.com
}

(C) Copyright: The Author(s)

This is an Open Access article distributed under the terms of the Creative Commons Attribution Non-Commercial License (https://creativecommons.org/licenses/by-nc/4.0/) which permits unrestricted non-commercial use, distribution, and reproduction in any medium, provided the original work is properly cited. rich spices (Thorburn, 2001). The area has a huge potential of natural resources, yet some districts such as Buru have a high poverty rate. The poverty depth and severity index stated by $\mathrm{P} 1$ and $\mathrm{P} 2$ show an increasing trend between 2015 2016. P1 slightly increased to 3.33 from 2.92 , which means an increase in low living standards and the poverty line on average. Likewise, P2 in 2016 increased to 1.00 from 0.67 in 2015 , indicating that poverty and income inequality slightly increased (BPS Kabupaten Buru, 2016).

An increase in the value of $\mathrm{P} 1$ indicates that the standard of living of the poor is declining. If spending falls further below the poverty line, it becomes challenging to mitigate the condition. In case the inequality among the poor increases (indicated by a considerable $\mathrm{P} 2$ value), it becomes hard to alleviate poverty. It is because of the differences in the expenditure levels among the poor, various poverty alleviation programs are required. Otherwise, poverty alleviation is likely to retreat. There has been a stable economic growth of Buru Regency, probably at 4-6\% (FAO, 2016; Permadi, 2017). However, statistics show that economic growth has not contributed significantly to poverty alleviation and the equal distribution of the development activities (Spiegel, 2012). 
The high economic growth increases the Indonesian financial capacity and the nation's income (Friedman, 2006; Lee \& Chang, 2008; Yoo \& Kim, 2006). The national development policy strategy is based on the assumption that the high economic growth automatically rises to equal welfare distribution as proposed by the trickle-down effect theory by Albert Otto Hirschman (1958) (Alacevich, 2017). For this reason, the purpose of this study was to (1) Identify the leading commodity in each district in Buru Regency; (2) Analyze the effect of road infrastructure and leading commodities on poverty in Buru Regency.

\section{Literature Review Hypothesis Development}

\subsection{The Concept of Infrastructure}

Infrastructure is a physical system that provides transportation, irrigation, drainage, buildings, and other public facilities necessary for the satisfaction of basic human needs in the socio-economic sphere (Srinivasu \& Srinivasa, 2013). It exists in two forms, economic and noneconomic. Industrial infrastructure is a setup where the market mechanism works, has a price, and those who benefit from it are required to pay for what they gain. The benefits received from this system include clean water installations, telecommunication networks, and energy sources. Usually, the procurement of economic infrastructure is carried out by the private sector and the government. Economic infrastructure refers to a system where the market mechanism does not work, and therefore there is no price. Private sectors are often unwilling to venture into this type of infrastructure, and thus the government has to provide it. The typical examples include roads, bridges, and irrigation.

In this global competition era, sustainable socioeconomic development cannot be achieved without adequate and efficient infrastructure facilities. The existence of such infrastructure facilitates and support economic activities, which ultimately strengthen economic growth in general. From the business community's standpoint, infrastructure incompleteness is the second most significant obstacle for doing business. This assertion is reinforced by the results of a collaborative study between the Islamic Development Bank (IDB), the Asian Development Bank (ADB), and the International Labor Organization (ILO). The study result indicates that infrastructure inadequacy is the main obstacle to economic growth (IDB, 2018).

\subsection{Infrastructure and Inclusive Growth}

Based on the general concepts proposed by various parties, inclusive growth is defined as the development which gives access to all groups of people and provides enough benefits to the community, and help to alleviate poverty
(Ali \& Zhuang, 2007; Anand et al., 2013; Ifzal \& Son, 2007; Klasen, 2017; McKinley, 2010; Rauniyar \& Kanbur, 2010). Several dimensions implicitly relate to the concept of economic growth, including income distribution, Gap (Gini ratio), absorption of labor described by the working population, and poverty.

The achievement of the whole growth dimension is affected by infrastructure development. For instance, infrastructure creates jobs and intensifies economic activities (Vandermeulen et al., 2011; Stilwell \& Primrose, 2010). Spending on infrastructure stimulates economic activities, increases opportunities, and eventually creates jobs (Seyfang, 2006). According to Calderon and Serven (2010), infrastructure has positive and negative impacts on economic growth and the Gap.

Road and electricity quality affects employment and income from non-farm people's businesses in rural areas (Gibson \& Olivia, 2010). The lack of access to road and electricity infrastructure and the low quality of infrastructure obstruct the non-farm household business in the rural area. Households without a non-farm business have low income compared to their counterparts. It is especially the case if they live in very remote areas, use poor road quality, have no electricity access, and often suffer from blackouts.

In their research on "Infrastructure and Poverty Linkages: A Literature Review", it showed that infrastructures in transportation, telecommunications, and energy has a significant impact on increasing economic growth (Brenneman \& Kerf, 2002). However, water and sanitation infrastructure development has not yet shown a significant impact.

\subsection{Economy Base Theory}

According to the economic base theory, the rate of commercial development of a region is determined by its exports, which involves selling products/services to other regions, either within the country or abroad. In general, economic activities are divided into two, base activities and non-base activities. The base economic activities refer to the growth of leading activities and determine the development of the whole region. It includes exporting goods and services activities to places outside the regional economic boundaries. In contrast, non-base economic activities involve providing goods needed by people who live within the local community (Tarigan, 2005).

The base analysis is concerned with identifying basic income. There is a direct relationship where income increases if the base is expanded (Sisco et al., 2012). The primary economic growth determinant in a region is directly related to the demand for goods and services from outside sources (Demurger, 2001). The industry growth, which uses local resources, including labor and raw materials for export, produces regional wealth 
and creates job opportunities. It means an area might have a superior sector if it wins over the competition in the same segment with other regions and export.

\subsection{Leading Commodities}

Leading commodities are superior commodities supplies with a strategic position to be developed in a specific region based on technical (land and climate conditions), socioeconomic, and institutional considerations. The determination of superior commodities in an area is significant because of the availability and ability of natural resources, capital, and human resources to produce and market. All items produced simultaneously in one area are relatively limited.

Determining the leading commodities is the first step towards agricultural development. This move should be based on efficiency to achieve comparative and competitive advantage to face global trade. The steps often taken to reach efficiency by developing commodities have a comparative advantage, both in supply and demand. Based on leading commodities supply, the most significant factor is the superiority of the growth in biophysical, technological, and socio-economic conditions in a specific region (Barrett et al., 2012; Borras et al., 2016; Bustamante et al., 2014).

\subsection{Leading Commodities and Poverty}

Poverty is multidimensional and has many aspects. It is manifested in malnutrition, unhealthy housing water, inadequate health care, and low education levels. The low life needs reflect the limited purchasing power of the people, which means that the level of consumption of the population is still below the poverty line. The income earned by the population mostly determines the consumption of goods and services. The higher the income earned, the higher the chances of living a poverty-free life. The low purchasing power is often attributed to a lack of income or just small earnings. Poor households are often linked to labor income, which depends on the structure of age, labor force participation rates, employment status, and wage levels (Lipton \& Ravallion, 1995).

An increase in the remuneration factor in wages and business surpluses boosts household income and needs to be carried out by improving production. In general, an increase in production expands the remuneration factor, which adds value to production. The addition of value means that there is economic growth, and thus households gain more income.

Growth is necessary in reducing poverty, though it is not sufficient in this regard. Economic growth that stands alone is like a knife that loses its sharpness or benefits for poverty alleviation (Venugopal, 2015). Elimination of poverty is useful if the resulting growth is balanced with a policy of income, assets, wealth, and skills redistribution (Bourguignon, 2004). The composition of sectoral growth influences development and has an impact on poverty. The economic sector growth where the poor are concentrated has a more significant impact on reducing poverty than in other economic sectors (Mallick, 2009).

\section{Research Methods}

This study uses secondary data from the Central Statistics Agency (BPS) and the Regional Development Planning Agency (BAPPEDA) of Buru Regency in 2016. The operational definition variables include; 1) Road infrastructure is the total length of national, provincial, and district/city roads in good condition in each sub-district, expressed in units of Kilo Meters (km); 2) Leading commodities are the results of agricultural and plantation products from each sub-district that is leading compared to other sub-districts, expressed in index numbers; 3 ) Poverty is a population that cannot meet the basic needs for a decent living for food and non-food aspects or has an average monthly per capita expenditure below the poverty line. The unit of poverty variable is the number of poor people in 2016 per thousand inhabitants.

The location quotient is used to reckon the main potential of the comparative advantage of certain commodities relative to other regions. LQ index is a simple indicator that shows the strength of a leading commodity in an area than the region above the reference location. It measures the concentration of activity in an area by comparing its role in the regional economy with similar activities or industries. The formula used to calculate LQ is as follows (Widodo, 2009).

$$
L Q i j=\frac{V i j / V j}{V i n / V n}
$$

Where;

$\mathrm{Vij}=i$ commodity production in $\mathrm{j}$ sub-district

$\mathrm{Vj}=$ total production in $j$ sub-district

Vin $=$ commodity production in $i$ regency

$\mathrm{Vn}=$ total regency production

Conditions apply, that if:

LQ $>1$ : Sub-district $j$ is more specialized in producing commodity $i$ compared to commodity $j$ district

LQ $<1$ : District $j$ does not specialize in producing commodity $i$ compared to commodity $j$ district

$\mathrm{LQ}=1$ : Both $j$ and $i$ districts have the same degree of specialization in producing commodities $i$

After finding leading commodities from each district, multiple linear regression tests were carried out to forecast the effect of independent variables such as road infrastructure and leading products on poverty as the dependent variable with the following linear regression equation.

$$
\mathrm{Y}=\mathrm{a}+\mathrm{b}_{1} \mathrm{X}_{1}+\mathrm{b}_{2} \mathrm{X}_{2}
$$


Where; $Y$ is the poverty variable; $a$ is a constant, the intersection of lines on the axis $X 1 ; b 1$ is the regression coefficient of the road infrastructure; $X 1$ is the road infrastructure; $b 2$ is the regression coefficient of the leading commodity, and $X 2$ is a superior commodity. This linear regression equation test was performed using statistical analysis tools.

\section{Results and Discussion}

\subsection{Leading Commodities Identification}

Each region has different characteristics, population, and resources. It means potential will be different in determining economic development policy direction activities in the area. One effort to improve the people's economy is by developing leading commodities to build a resilient economic structure to avoid poverty.

From each district in Buru Regency, the LQ analysis on agricultural commodities, which consists of vegetables, fruits, and plantation commodities, shows that each district has its leading products, as shown in Table 1. Based on the LQ calculation, Batabual District produces a lot of superior commodities with 16 leading crops. The region with the fewest leading products is Lilialy District, with only 11 . The highest LQ value is cashew $(22,17)$, followed by shallot $(11,94)$ in Waplau District. The other leading commodities with double-digit LQ value include langsat with 12.57 in Batabual and melon located in Kaiely Bay with 10.23.

High LQ value indicates that these commodities relatively have outstanding potential to be developed in the future compared to other districts. All leading commodities (LQ value $=$ or $>1)$ means that the population meets their daily needs with industrial goods, or the district export products out of the region. The main commodity has the potential to be developed in various sub-districts in Buru Regency. The development of superior agricultural products has added value to various economic aspects in line with increasing population, consumption, income, and employing ecological and geographical conditions in several sub-districts possible to develop.

The development of superior commodities in each district has a positive impact. Sub-districts that have excellent commodities and have competitive and comparative advantages supply to those sub-districts that do not have superior commodities. As such sub-districts having superior commodities can use their expertise in providing benefits and developing the main commodity of those sub-districts that do not have superior commodities. Utilization of knowledge improves the people's welfare so that it can reduce poverty levels.

Prioritizing superior commodities does not mean ignoring the potential of other products. Even non-potential commodities still need to be developed and considered. As a stakeholder, the government must plan development synergy of all commodities by prioritizing superior products to provide maximum future benefits. Also, the government must continue to pay attention to other commodities that are less superior and strive for non-superior specialties because these products are people's basic living needs.

\subsection{Leading Commodities and Poverty}

Poverty often occurs in rural areas, which are identical to agricultural fields. Farmer poverty is caused by several main problems such as 1) low farmer education; 2) limited access ; 3) the agricultural land is scattered in various places and within their respective narrow areas, management has not led to intensive business; 4) weak and low technology, productivity, labor, human resources, and capital; 5) social and economic institutions not able to support farming, distribution, and marketing activities as well as lack of information and technology experts; and 6) the selling price of production fluctuates (Davis et al., 2012; Tittonell \& Giller, 2013). Furthermore, programs need to be developed in rural areas to improve the agricultural sector and small industries, creating superior commodities (Wahyuningsih, 2016).

The LQ underlying logic is an economic base theory, which states that the base industry produces goods and services for markets within and outside the region, generating income. Furthermore, income inflow leads to increased consumption and investment in the area, increased income, and new job opportunities. It increases the demand for the base and non-base local industries (Banerjee et al., 2018; Yuwono \& Nugroho, 2016). Also, it encourages an increase in investment in the related industries.

Table 2 presents the number of poor people and the leading commodities ranked from the most significant to the smallest. The data in Table 2 shows Fena Leisela sub-district has the highest poverty rate, which is 7,713 people or $18.05 \%$ of the total sparse population in Buru Regency. The leading commodity that needs to be developed in this area to mitigate the sparse population is mango. However, other products such as cayenne pepper, bird eye chilies, tomatoes, yard-long beans, spinach, water spinach, avocado, durian, papaya, banana, cocoa, and nutmeg are also essential. The district with the second-largest number of sparse population is Air Buaya with 6,341 people or $14.84 \%$. The main commodity is pineapple, followed by papaya, cayenne pepper, bird eye chilies, tomatoes, eggplant, yard-long beans, green beans, spinach, water spinach, mango, durian, banana, nutmeg, and cocoa.

Waeapo District has the lowest number of poor people with 1,524 individuals or $3.57 \%$, with watermelon as the leading commodity, followed by pineapple, cucumber, eggplant, mustard green, green beans, spinach, chayote, durian, tangerine, rambutan, cocoa, and coffee beans. The results of superior commodities identification are the Buru local government's knowledge of planning regional economic development strategies. By knowing a comparative advantage, regional development strategies must focus on developing this advantage to encourage increased competitiveness of its products in local and global markets. 
Table 1: Location Quotient (LQ) Index On Each Sub-Districts of Buru Region

\begin{tabular}{|c|c|c|c|c|c|c|c|c|c|c|}
\hline Commodities & 1 & 2 & 3 & 4 & 5 & 6 & 7 & 8 & 9 & 10 \\
\hline \multicolumn{11}{|l|}{ Vegetables } \\
\hline Shallot & 0.00 & 0.00 & 11.94 & 0.00 & 0.00 & 0.00 & 0.00 & 0.00 & 0.00 & 0.00 \\
\hline Cayenne Pepper & 0.80 & 0.86 & 1.05 & 0.82 & 1.22 & 1.00 & 1.04 & 0.89 & 1.31 & 1.15 \\
\hline Bird Eye Chillies & 1.07 & 0.88 & 0.66 & 1.11 & 0.69 & 0.96 & 1.30 & 0.88 & 1.18 & 1.18 \\
\hline Tomatoes & 0.80 & 0.84 & 1.05 & 1.17 & 0.98 & 1.10 & 0.82 & 1.26 & 1.08 & 1.18 \\
\hline Cucumber & 1.42 & 1.56 & 1.02 & 0.00 & 1.14 & 1.21 & 0.89 & 1.69 & 0.00 & 0.00 \\
\hline Egg plant & 1.14 & 1.05 & 0.58 & 0.83 & 0.53 & 1.14 & 1.26 & 0.84 & 1.47 & 0.68 \\
\hline Yardlong bean & 0.99 & 0.68 & 1.16 & 1.06 & 1.34 & 1.09 & 0.75 & 1.10 & 1.02 & 1.53 \\
\hline Cabbage & 0.00 & 0.00 & 0.00 & 0.00 & 0.00 & 0.00 & 6.01 & 0.00 & 0.00 & 0.00 \\
\hline Mustard green & 0.00 & 1.92 & 1.57 & 0.00 & 0.00 & 0.00 & 3.22 & 0.00 & 0.00 & 0.00 \\
\hline Green Beans & 1.24 & 1.39 & 0.83 & 0.74 & 1.00 & 0.80 & 1.13 & 0.83 & 1.34 & 0.00 \\
\hline Spinach & 1.09 & 1.08 & 0.96 & 1.40 & 1.36 & 0.83 & 0.46 & 0.92 & 1.07 & 1.69 \\
\hline Chayote & 0.88 & 1.27 & 0.82 & 1.35 & 0.65 & 1.38 & 1.52 & 1.01 & 0.00 & 0.00 \\
\hline Water Spinach & 1.03 & 0.89 & 0.81 & 1.33 & 1.17 & 0.91 & 0.62 & 1.08 & 1.19 & 1.73 \\
\hline \multicolumn{11}{|l|}{ Fruit } \\
\hline Avocado & 2.01 & 0.59 & 2.48 & 1.33 & 0.75 & 0.68 & 1.38 & 0.00 & 0.78 & 1.38 \\
\hline Tangerine & 0.43 & 1.53 & 0.65 & 1.00 & 0.03 & 0.94 & 1.95 & 0.15 & 0.52 & 0.33 \\
\hline Langsat & 0.00 & 0.00 & 0.00 & 12.57 & 0.00 & 0.00 & 0.00 & 0.00 & 0.00 & 0.00 \\
\hline Mango & 1.11 & 0.72 & 0.28 & 0.89 & 0.19 & 1.47 & 1.14 & 1.99 & 1.54 & 2.29 \\
\hline Durian & 0.00 & 1.38 & 0.00 & 1.23 & 1.23 & 0.12 & 0.94 & 0.00 & 1.52 & 1.51 \\
\hline Papaya & 1.36 & 0.42 & 1.14 & 1.33 & 0.87 & 0.61 & 1.82 & 1.19 & 2.17 & 1.50 \\
\hline Pineapple & 0.00 & 2.56 & 0.00 & 0.00 & 0.00 & 0.00 & 0.00 & 0.00 & 9.00 & 0.00 \\
\hline Banana & 2.12 & 0.22 & 2.35 & 1.48 & 0.41 & 1.68 & 0.48 & 1.99 & 1.37 & 1.21 \\
\hline Rambutan & 0.00 & 1.28 & 0.00 & 6.30 & 0.00 & 0.00 & 0.00 & 0.00 & 0.00 & 0.00 \\
\hline Rose Apple & 0.00 & 0.00 & 22.17 & 0.00 & 0.00 & 0.00 & 0.00 & 0.00 & 0.00 & 0.00 \\
\hline Dragon fruit & 1.16 & 0.52 & 0.00 & 0.00 & 0.00 & 3.44 & 8.69 & 0.00 & 0.00 & 0.00 \\
\hline Melon & 0.00 & 0.98 & 0.00 & 0.00 & 10.23 & 0.00 & 0.00 & 0.00 & 0.00 & 0.00 \\
\hline Watermelon & 0.00 & 2.56 & 0.00 & 0.00 & 0.00 & 0.00 & 0.00 & 0.00 & 0.00 & 0.00 \\
\hline \multicolumn{11}{|l|}{ Plantation } \\
\hline Coconut & 1.33 & 0.47 & 1.86 & 0.84 & 1.00 & 0.62 & 0.28 & 0.82 & 0.71 & 0.95 \\
\hline Nutmeg & 0.00 & 0.00 & 0.00 & 2.67 & 0.00 & 0.00 & 0.00 & 0.00 & 1.43 & 1.13 \\
\hline Cacao & 0.23 & 1.63 & 0.42 & 0.97 & 1.00 & 1.46 & 1.67 & 0.62 & 1.34 & 1.19 \\
\hline Clover & 0.00 & 0.09 & 0.00 & 3.41 & 1.00 & 0.27 & 0.24 & 0.00 & 0.94 & 0.81 \\
\hline Coffee & 0.00 & 1.26 & 0.00 & 1.15 & 6.72 & 4.52 & 5.60 & 0.00 & 0.27 & 0.35 \\
\hline Cashew & 5.20 & 0.25 & 1.36 & 0.14 & 0.51 & 0.13 & 0.38 & 5.22 & 0.28 & 0.25 \\
\hline
\end{tabular}

Note: (1) Namlea, (2) Waeapo, (3) Waplau, (4) Batabual, (5) Kaiely Bay, (6) Waelata, (7) Lolong Guba, (8) Lilialy, (9) Air Buaya, (10) Fena Leisela. 
Table 2: The Poor Rank and The Leading Commodities for Each Sub-District in Buru Region

\begin{tabular}{|c|c|c|}
\hline Rank & Sub-District & Leading Commodities \\
\hline $1=7.713$ inhabitants $(18,05 \%)$ & Fena Leisela & $\begin{array}{l}\text { Mango; Cayenne Pepper; Birds Eye Chillies; Tomatoes; Yardlong } \\
\text { Beans; Spinach; Water Spinach; Avocado; Durian; Papaya; } \\
\text { Banana; Cocoa; Nutmeg. }\end{array}$ \\
\hline $2=6.341$ inhabitants $(14,84 \%)$ & Air Buaya & $\begin{array}{l}\text { Pineapple; Papaya; Cayenne Pepper; Birds Eye Chillies; Tomatoes; } \\
\text { Eggplant; Yardlong Beans; Green beans; Spinach; Water Spinach; } \\
\text { Mango; Durian; Banana; Nutmeg; Cocoa. }\end{array}$ \\
\hline $3=5.032$ inhabitants $(11,78 \%)$ & Batabual & $\begin{array}{l}\text { Langsat; Rambutan; Clover; Nutmeg; Coffee beans; Birds Eye } \\
\text { Chillies; Tomatoes; Yardlong Beans; Spinach; Chayote; Water } \\
\text { Spinach; Avocado; Tangerine; Durian; Papaya; Banana. }\end{array}$ \\
\hline $4=5.004$ inhabitants $(11,71 \%)$ & Waplau & $\begin{array}{l}\text { Rose Apple; Shallot; Cayenne Pepper; Tomatoes; Cucumber; } \\
\text { Yardlong Beans; Mustard Green; Avocado; Papaya; Banana; } \\
\text { Coconut; Cashew. }\end{array}$ \\
\hline $5=4.374$ inhabitants $(10,24 \%)$ & Lolong Guba & $\begin{array}{l}\text { Kubis; Coffee beans; Mustard Green; Cayenne Pepper; Birds Eye } \\
\text { Chillies; Eggplant; Green beans; Chayote; Avocado; Tangerine; } \\
\text { Mango; Papaya; Cocoa. }\end{array}$ \\
\hline $6=3.943$ inhabitants $(9,23 \%)$ & Lilialy & $\begin{array}{l}\text { Cashew; Tomatoes; Cucumber; Yardlong Beans; Chayote; Water } \\
\text { Spinach; Mango; Papaya; Banana. }\end{array}$ \\
\hline $7=3.813$ inhabitants $(8,93 \%)$ & Waelata & $\begin{array}{l}\text { Coffee beans; Cayenne Pepper; Tomatoes; Cucumber; Eggplant; } \\
\text { Yardlong Beans; Chayote; Mango; Banana; Dragon fruit; Cocoa. }\end{array}$ \\
\hline $8=3.306$ inhabitants $(7,74 \%)$ & Namlea & $\begin{array}{l}\text { Cashew; Banana; Avocado; Cucumber; Papaya; Coconut; Green } \\
\text { beans; Eggplant; Spinach; Water Spinach; Mango; Dragon fruit; } \\
\text { Birds Eye Chillies. }\end{array}$ \\
\hline $9=1.670$ inhabitants $(3,91 \%)$ & Teluk Kaiely & $\begin{array}{l}\text { Melon; Coffee beans; Cayenne Pepper; Cucumber; Yardlong } \\
\text { Beans; Green beans; Spinach; Water Spinach; Durian; Coconut; } \\
\text { Cocoa; Clover }\end{array}$ \\
\hline $10=1.524$ inhabitants $(3,57 \%)$ & Waeapo & $\begin{array}{l}\text { Watermelon; Pineapple; Cucumber; Eggplant; Mustard Green; } \\
\text { Green beans; Spinach; Chayote; Durian; Tangerine; Rambutan; } \\
\text { Cocoa; Coffee beans. }\end{array}$ \\
\hline
\end{tabular}

The study results show that each sub-district has more than one superior commodity developed as the people's economic basis. The local government of the Buru Regency can increase the purchasing people's power by creating economic development programs through commodities development that have been identified in each district as the leading commodity in reducing poverty.

The test results of the influence of leading commodities on poverty had a regression coefficient of $-7,733$, which indicates that each addition of 1 ton of leading products would reduce the number of poor people by seven. However, the regression test did not show a significant effect. An increase in the production of leading commodities developed in each district is expected to reduce the number of poor Buru Regency people.

The development of the agricultural sector has added value to various aspects of the economy in line with the increasing population, increasing consumption, income, and employment. Regional superior commodities are expected to create opportunities for developing other related sectors, both as input for potential industries and the increased demand for labor in leading commodities with increased incomes. It allows the development of superior entities to be done as a first step in improving the regional economy. The programs need to be developed in rural areas to build and develop agricultural and small industries by producing only commodities (Ihnatenko \& Novak, 2018).

The test results on the effect of superior commodities on poverty in Buru Regency show a regression coefficient of -70.905 as in Table 3, which indicates that each addition of 1 ton of excellent commodities will reduce the poor people's number by 70 people. Although the regression test does not show a significant effect, with an increase in the production of superior commodities developed in each district, the poverty level in Buru Regency is expected to decline. 
Table 3: Road Infrastructure Regression Coefficient and Leading Commodities on Poverty in Buru Region

\begin{tabular}{|l|l|c|c|c|c|c|}
\hline \multirow{2}{*}{ Model } & \multicolumn{2}{|c|}{ Unstandardized Coefficients } & \multicolumn{1}{c|}{$\begin{array}{c}\text { Standardized } \\
\text { Coefficients }\end{array}$} & \multirow{2}{*}{ t } & \multirow{2}{*}{ Sig. } \\
\cline { 3 - 7 } & & B & Std. Error & Beta & & \\
\hline \multirow{3}{*}{1} & (Constant) & 6513.150 & 1239.345 & & 5.255 & .001 \\
\cline { 2 - 7 } & Good_Road & -168.415 & 62.768 & -.774 & -2.683 & .031 \\
\cline { 2 - 7 } & Leading_Commodities & -70.905 & 145.629 & -.140 & -.487 & .641 \\
\hline
\end{tabular}

a. Dependent Variable: POVERTY

Leading commodities have no significant effect on poverty in Buru Regency. This condition can be caused by several factors, as follows. Generally, superior commodities' productivity is still low due to technical mastery and low human resource capacity, and limited business capital. The increase in the quality and quantity of annual production is low. The community's processing and packaging businesses are still weak; generally, there has been no effort to preserve the superior commodity products produced. The excellent commodity products made have not been standardized as such their competitiveness is still low. Marketing activities for agricultural products are still through traditional markets, and there is a lack of promotion of superior commodity products. Farmer poverty is caused by several main problems (Wahab, 2004), such as:

1. Low farmer education.

2. Limited access to farmers.

3. Agricultural land is scattered in various places and within their respective narrow areas, their management has not led to intensive business.

4. Weak and low technology, productivity, labor, human resources, and capital.

5. At the farm level, social and economic institutions have not supported farming activities, distribution and marketing, and there is a lack of information and technology experts.

6. The selling price of products fluctuates.

These superior commodities significantly affect poverty. It is necessary to strengthen agricultural product processing efforts, including post-harvest handling activities and produce fresh products, main processed products, byproducts, and waste products marketing development, in both domestic and global markets. Efforts to increase and create added value of this prime agricultural commodity is made by strengthening farm areas' poor population skills (Aerni et al., 2015). The new paradigm in poverty reduction in rural development is where agriculture is positioned as a promising income source and adequate results (Vicol et al., 2018). Agriculture can be an appropriate income source if each program involves active community participation in rural areas, around $75 \%$ of the total population, and certainly adjusted to human resources potential cases and natural resources (Bene et al., 2016).

\subsection{Infrastructure and Poverty}

In developing superior commodities in the Buru Regency context, infrastructure development is also needed so that the superior commodity provides people added value. The infrastructure needs include; a) training and counseling for farmers related to pre-harvest, harvest, and post-harvest, b) training and advice to promote the marketing of products, c) developing farm roads and production roads at leading commodity development sites, d) processing equipment for superior commodity. Among the supporting infrastructure needed for superior commodity utilization, which is the most critical consideration in the Buru Regency, is road infrastructure that can help facilitate the mobilization/ transport of the superior commodity. In line with Atika et al. (2017) and Mawardi et al. (2011), in areas where there are limitations of natural resources, human resources, and other development resources, development priorities concerning regional excellence is needed.

To support superior commodities development, it must be supported by proper road infrastructure, else it will be impossible to develop leading commodities which is the main driving factor in reducing poverty. In line with Amelia (2019), infrastructure is a driving force in economic growth. Therefore, some empirical facts indicate that infrastructure capacity development in a region will go hand in hand with economic output development (Amelia, 2019).

Liner regression test results, as shown in Table 3, shows the regression coefficient is $-168,415$, which indicates that every addition of $1 \mathrm{~km}$ of road infrastructure will reduce the number of poor people by 168 people. The regression coefficient value of 0.031 indicates that infrastructure has a significant effect on poverty in Buru Regency. It suggests that the role of infrastructure plays a crucial role in reducing poverty in Buru Regency. If the road infrastructure is in good and improved condition, the number of poor people in Buru Regency is expected to decrease. 
Good road infrastructure can promote connectivity between regions so that it can accelerate and expand economic development. The provision of infrastructure that encourages connectivity will reduce transportation costs and logistics costs to increase product competitiveness and accelerate economic growth. If the road infrastructure condition is not good can affect investment attractiveness because investment in infrastructure has a relatively uncertain, it profit prospect, which causes low private participation. When the road infrastructure in Buru Regency improves and new roads are built, it can improve transportation access, reduce the living costs of the poor and increase income, and open up opportunities for the poor to benefit from economic growth. Thus, good road infrastructure is expected to have a significant effect on poverty reduction in Buru Regency.

The insignificance of proper road infrastructure to the poor is mainly attributed to the lack of good roads. Based on the data in Table 4, the road infrastructure condition in all sub-districts is majorly damaged or badly damaged. The problem of road infrastructure in the Buru Regency attributes to the low quality of structures and service coverage, which is still very limited. Statistical data in Table 5 shows the number of damaged and heavily damaged roads compared to the good roads in Buru Regency. Low-quality roads increase the number of damaged and heavily damaged roads. Moreover, the districts located far from the capital regency such as Batabual, Kaiely Bay, Waelata, Lolong Guba, and Fena Leisela have only around $2.30 \mathrm{~km}$ to $4.89 \mathrm{~km}$ roads in good conditions.

It shows that infrastructure support, especially village road infrastructure and farm roads, to improve leading commodity accessibility to the marketneeds to be addressed so that farmers' access is easily affordable and does not increase the cost of distributing goods or crops. With such road conditions, it is not easy for remote areas farmers to market their agricultural products. Even if they can, the farmers who do not have much income, have to pay a high cost. The obstacles prevent the poor from participating in the development process, to get better jobs, or increase work productivity. Excellent road infrastructure can encourage connectivity between regions so that it can accelerate and expand economic development. The infrastructure provision supports connectivity will reduce transportation costs and logistics costs to increase product competitiveness and accelerate the economic movement. In contrast, road infrastructure conditions cannot affect investment attractiveness because investment in infrastructure has a relatively uncertain profile prospect that causes low private participation.

When road infrastructure in Buru Regency is improved, and many new roads are built, it can improve transportation access, reduce the living costs of the poor, and increase income and open opportunities to benefit from economic growth. Therefore, excellent road infrastructure is expected to have a significant effect on poverty reduction in Buru Regency.

\section{Conclusions}

The most significant poor population in Buru Regency is Fena Leisela District, with mango as the leading commodity. Then followed by Air Buaya District with pineapple as the leading commodity, Batabual District with langsat as the leading commodity, Waplau District with guava as the leading commodity, Lolong Guba District with cabbage as the leading commodity, Lilialy District with cashew as the leading commodity, Waelata District with coffee as the leading commodity, Namlea District with cashew as the leading commodity, Teluk Kaiely with melon as the leading commodity, and Waeapo District with watermelon as the leading commodity. Recommendations to the local government are increasing investment growth and expanding the business by focusing on superior commodities in each district by paying attention to market and resource aspects and produce quality and large-scale commodities to increase the poor's income.

Good road infrastructure has a significant effect on poverty, while superior commodities impact poverty but not significantly. One of the steps in reducing poverty in the Buru Regency agricultural sector is developing superior commodities through upstream-downstream agribusiness. It is done by strengthening farmer and group partnerships, and entrepreneurs (market access), increasing skills according to needs and based on local resources, creating and developing integrated agribusiness areas based on local resources.

\section{References}

Aerni, P., Nichterlein, K., Rudgard, S., \& Sonnino, A. (2015). Making agricultural innovation systems (AIS) work for development in tropical countries. Sustainability, 7(1), 831850. https://doi.org/10.3390/su7010831

Alacevich, M. (2017). Development economics, and the social sciences. Paper presented at the First Conference on Albert Hirschman's Legacy: Theory and Practice, October 6-7, 2017, Boston University, Pardee School of Global Studies. https:// media.entopanlab.it/storage/colorni/media/pdf/Alacevich.pdf

Ali, I., \& Zhuang, J. (2007). Inclusive growth toward a prosperous Asia: Policy implications. Working Paper. Asian Development Bank. https://www.adb.org/sites/default/files/ publication/28210/wp097.pdf

Amelia, S. (2019). Development of leading commodities and infrastructure as efforts to improve community welfare and development of district strategic areas in Bengkulu Tengah Regency. Proceedings SEMNASTEK.

Anand, R., Mishra, S., \& Peiris, S. J. (2013). Inclusive growth: Measurement and determinants. IMF Working Papers, 13(135), 1. https://doi.org/10.5089/9781484323212.001

Atika, W., Glasbergenc, P., \& Mawardid, S. (2017). The mediated partnership model for sustainable coffee production: 
Experiences from Indonesia. International Food and Agribusiness Management Review, 20(5), 689-708. https://doi. org/10.22434/IFAMR2017.0021

Banerjee, O., Cicowiez, M., Ochuodho, T., Masozera, M., Wolde, B., Lal, P., Dudek, S., \& Alavalapati, J. R. R. (2018). Financing the sustainable management of Rwanda's protected areas. Journal of Sustainable Tourism, 26(8), 1381-1397. https://doi. org/10.1080/09669582.2018.1456541

Barrett, C. B., Bachke, M. E., Bellemare, M. F., Michelson, H. C., Narayanan, S., \& Walker, T. F. (2012). Smallholder participation in contract farming: Comparative evidence from five countries. World Development, 40(4), 715-730. https://doi.org/10.1016/j. worlddev.2011.09.006

Béné, C., Arthur, R., Norbury, H., Allison, E. H., Beveridge, M., Bush, S., Campling, L., Leschen, W., Little, D., Squires, D., Thilsted, S. H., Troell, M., \& Williams, M. (2016). Contribution of fisheries and aquaculture to food security and poverty reduction: Assessing the current evidence. World Development, 79, 177-196. https://doi.org/10.1016/j.worlddev.2015.11.007

Borras, S. M., Franco, J. C., Isakson, S. R., Levidow, L., \& Vervest, P. (2016). The rise of flex crops and commodities: Implications for research. Journal of Peasant Studies, 43(1), 93-115. https:// doi.org/10.1080/03066150.2015.1036417

Bourguignon, F. (2004). The poverty-growth-inequality triangle. Working Paper No. 125. Indian Council for Research on International Economic Relations (ICRIER). http://www.icrier. org/pdf/wp125.pdf.

BPS Kabupaten Buru. (2016). Buru Regency in Figures 2016. BPSStatistics of Buru Regency, Indonesia.

Brenneman, A., \& Kerf, M. (2002). Infrastructure \& poverty linkages: A literature review. Washington, DC: The World Bank.

Bustamante, M., Robledo-Abad, C., Harper, R., Mbow, C., Ravindranat, N. H., Sperling, F., Haberl, H., Pinto, A. de S., \& Smith, P. (2014). Co-benefits, trade-offs, barriers and policies for greenhouse gas mitigation in the agriculture, forestry and other land use (AFOLU) sector. Global Change Biology, 20(10), 3270-3290. https://doi.org/10.1111/gcb.12591

Calderon, C., \& Serven, L. (2010). Infrastructure and economic development in Sub-Saharan Africa. Journal of African Economies, 19(Supplement 1),i13-i87. https://doi.org/10.1093/ jae/ejp022

Davis, K., Nkonya, E., Kato, E., Mekonnen, D. A., Odendo, M., Miiro, R., \& Nkuba, J. (2012). Impact of farmer field schools on agricultural productivity and poverty in East Africa. World Development, 40(2), 402-413. https://doi.org/10.1016/j. worlddev.2011.05.019

Démurger, S. (2001). Infrastructure development and economic growth: an explanation for regional disparities in China? Journal of Comparative Economics, 29(1), 95-117. https://doi. org/10.1006/jcec.2000.1693

FAO. (2016). Socio-economics of trawl fisheries in Southeast Asia and Papua New Guinea. Proceedings of the Regional Workshop on Trawl Fisheries Socio-economics 26-27 October 2015 (Issue April).

Friedman, B. M. (2006). Economic growth: moral consequences. Current, 481, 9-16.

Gibson, J., \& Olivia, S. (2010). The effect of infrastructure access and quality on non-farm enterprises in rural Indonesia. World Development, 38(5), 717-726. https://doi.org/10.1016/j. worlddev.2009.11.010

Ifzal, A., \& Son, H. H. (2007). Measuring inclusive growth. Asian Development Review, 24(1), 11-31. https://doi.org/10. 1177/002795011924700110

Ihnatenko, M., \& Novak, N. (2018). Development of regional programs for the development of agrarian enterprises with organic production on the basis of the European and International Experience. Baltic Journal of Economic Studies, 4(4), 126-133. https://doi.org/10.30525/2256-0742/2018-4-4126-133

Klasen, S. (2017). Measuring and monitoring inclusive growth in developing and advanced economies: Multiple definitions, open questions and some constructive proposals. Reframing Global Social Policy: Social Investment for Sustainable and Inclusive Growth, 12, 123-144.

Lee, C. C., \& Chang, C. P. (2008). Energy consumption and economic growth in Asian economies: A more comprehensive analysis using panel data. Resource and Energy Economics, 30(1), 50-65. https://doi.org/10.1016/j.reseneeco.2007.03.003

Lipton, M., \& Ravallion, M. (1995). Chapter 41 Poverty and policy. In: Handbook of Development Economics, 3(PART B), 2551-2657. https://doi.org/10.1016/S15734471(95)30018-X

Mallick, K. S. (2009). Macroeconomic policy and poverty reduction. In: IGIDR Proceedings/Project Reports Series.

Mawardi, M. K., Choi, T., \& Perera, N. (2011). The factors of SME cluster developments in a developing country : the case of Indonesian clusters. In: 2011 ICSB World Conference (pp. 408-408). Stockholm, Sweden: ICSB. https://ro.uow.edu.au/ gsbpapers/45/

McKinley, T. (2010). Inclusive growth criteria and indicators: an inclusive growth index for diagnosis of country progress. Asian Development Bank Working Paper, 14, 1-34.

Rauniyar, G., \& Kanbur, R. (2010). Inclusive development: two papers on conceptualization, application, and the ADB perspective. Working Papers No. 57036, Cornell University, Department of Applied Economics and Management. https:// doi.org/10.22004/ag.econ.57036

Seyfang, G. (2006). Sustainable consumption, the new economics and community currencies: Developing new institutions for environmental governance. Regional Studies, 40(7), 781-791. https://doi.org/10.1080/00343400600959173

Sisco, M., Du, H., Warner, J. P., Howard, M. A., Winchester, D. P., \& Yao, K. (2012). Have we expanded the equitable delivery of postmastectomy breast reconstruction in the new millennium? Evidence from the national Cancer data base. Journal of the 
American College of Surgeons, 215(5), 658-666. https://doi. org/10.1016/j.jamcollsurg.2012.07.008

Spiegel, S. J. (2012). Governance Institutions, resource rights regimes, and the informal mining sector: regulatory complexities in Indonesia. World Development, 40(1), 189-205. https://doi. org/10.1016/j.worlddev.2011.05.015

Srinivasu, B., \& Srinivasa, P. R. (2013). Infrastructure development and economic growth: Prospects and perspective. Journal of Business Management \& Social Sciences Research, 2(1), 2319-5614.

Stilwell, F., \& Primrose, D. (2010). Economic stimulus and restructuring: Infrastructure, green jobs and spatial impacts. Urban Policy and Research, 28(1), 5-25. https://doi. org/10.1080/08111141003610046

Tarigan, R. (2005). An evaluation of the relationship between alignment of strategic priorities and manufacturing performance. International Journal of Management, 22(4), 586.

Thorburn, C. C. (2001). The House that poison built : Customary marine property rights and the live food fish trade in the Kei Islands, Southeast Maluku. Development and Change, 32(1), 151-180, https://doi.org/10.1111/1467-7660.00200.

Tittonell, P., \& Giller, K. E. (2013). When yield gaps are poverty traps: The paradigm of ecological intensification in African smallholder agriculture. Field Crops Research, 143, 76-90. https://doi.org/10.1016/j.fcr.2012.10.007
Vandermeulen, V., Verspecht, A., Vermeire, B., Van Huylenbroeck, G., \& Gellynck, X. (2011). The use of economic valuation to create public support for green infrastructure investments in urban areas. Landscape and Urban Planning, 103(2), 198-206. https://doi.org/10.1016/j.landurbplan.2011.07.010

Venugopal, R. (2015). Neoliberalism as concept. Economy and Society, 44(2), 165-187. https://doi.org/10.1080/03085147.20 15.1013356

Vicol, M., Neilson, J., Faila, D., Hartatri, S., \& Cooper, P. (2018). Upgrading for whom? Relationship coffee, value chain interventions, and rural development in Indonesia. World Development, 110, 26-37. https://doi.org/10.1016/j. worlddev.2018.05.020

Wahyuningsih, T. (2016). The development strategy of main commodities of rice in Buru District, Maluku. World Journal of Agricultural Research, 4(1), 9-17. https://doi.org/10.12691/ wjar-4-1-2

Widodo, T. (2009). Comparative advantage: Theory, empirical measures and case studies. Review of Economic and Business Studies, 4, 57-83.

Yoo, S. H., \& Kim, Y. (2006). Electricity generation and economic growth in Indonesia. Energy, 31(14), 2890-2899. https://doi. org/10.1016/j.energy.2005.11.018

Yuwono, R., \& Nugroho, Y. (2016). Linkages, potential and spatial efficiency. Journal of Developing Economics, 1(1), 29-43. https://doi.org/10.20473/jde.v1i1.1737 